\title{
Nursing Faculty's Needs of Knowledge, Beliefs, and Readiness to Implement Interprofessional Education in their Teaching: An Exploratory Study
}

\author{
Louise Racine \\ University of Saskatchewan, louise.racine@usask.ca \\ Hope Bilinski \\ University of Saskatchewan, hope.bilinski@usask.ca \\ Paul Spriggs \\ University of Saskatchewan, paulspriggs@gmail.com
}

Follow this and additional works at: https://qane-afi.casn.ca/journal

Part of the Higher Education Commons, Nursing Commons, Other Life Sciences Commons, and the Teacher Education and Professional Development Commons

\section{Recommended Citation}

Racine, Louise; Bilinski, Hope; and Spriggs, Paul (2016) "Nursing Faculty's Needs of Knowledge, Beliefs, and Readiness to Implement Interprofessional Education in their Teaching: An Exploratory Study," Quality Advancement in Nursing Education - Avancées en formation infirmière: Vol. 2: Iss. 1, Article 2.

DOI: https://doi.org/10.17483/2368-6669.1064

This Article is brought to you for free and open access by Quality Advancement in Nursing Education - Avancées en formation infirmière. It has been accepted for inclusion in Quality Advancement in Nursing Education - Avancées en formation infirmière by an authorized editor of Quality Advancement in Nursing Education - Avancées en formation infirmière. 


\section{Nursing Faculty's Needs of Knowledge, Beliefs, and Readiness to Implement Interprofessional Education in their Teaching: An Exploratory Study}

\section{Cover Page Footnote}

We acknowledge the funding received from the Faculty and Staff Professional Development Committee of the College of Nursing at the University of Saskatchewan. We also express our heartfelt thanks the participants who took the time out of their busy schedule to answer this survey. Nous remercions le Comité de développement professionnel du corps professoral et du personnel du Collège des sciences infirmiers à l'University of Saskatchewan pour son appui financier. Nous exprimons également nos remerciements les plus sincères aux participants qui ont pris le temps, malgré leur horaire chargé, de répondre au sondage. 


\section{Introduction}

Over the past 15 years, the literature on interprofessional education (IPE) has exploded in nursing and other healthcare disciplines. The rise of interest in interprofessional practice and education is shared by health educators in Canada (Bilodeau, Dubois, \& Pepin, 2013; D'Amour \& Oandasan, 2005; Gilbert, 2005a; Pfaff, Baxter, Jack, \& Ploeg, 2013), the United Kingdom (Barr \& Low, 2013; Barr, Helme, \& D’Avray, 2011; Lewy, 2010; Reeves, Perrier, Golman, Freeth, \& Zwarenstein, 2013), the United States of America (Lash et al., 2014), and Norway (Kyrkjebø, Brattebø, \& Smith-Strøm, 2006).

The drive towards IPE cannot be isolated from political and financial factors that affect Western countries and the demands for knowledge and skills required to face the health challenges of the 21st century (Barr et al., 2011). Demographic aging, health inequities, higher prevalence of non-communicable illnesses, and the rise of health care expenditures create the needs for interprofessional health education (Côté, Lauzon, \& Kyd-Strickland, 2008; Ravet, 2012).

Ho et al. (2008) define IPE as "any form of health training that emphasizes the team learning of students from a variety of health professions" (p. 934). Despite inconclusive evidence linking IPE and its effectiveness regarding specific patient health outcomes (Reeves et al., 2013), IPE is increasingly seen as an effective way to prepare students for collaborative practice. IPE develops competencies for supporting the "effective and efficient use of healthcare resources" (Ho et al., 2008, p. 934). IPE decreases rigid professional boundaries and promotes communication and teamwork (Barr et al., 2011) to focus on providing client-centered care (Meffe, Moravac, \& Espin, 2012). Despite this substantial body of knowledge on interprofessional health education, the interface between interprofessional health education and faculty development deserves further examination (Simmons et al., 2011). Eleven years after Steinert (2005) raised concerns about the lack of interprofessional faculty development programs, this gap in knowledge in nursing education remains a critical issue.

The purpose of this paper is to present the results of a pilot study that assessed nursing faculty`s knowledge, skills, and readiness to apply IPE to their teaching. The objectives of this pilot study were to a) identify faculty's needs for faculty development, b) explore faculty's knowledge of IPE, c) assess faculty readiness to implement IPE within teaching activities, and d) understand perceived barriers and beliefs in IPE.

\section{Background}

Quantitative and qualitative evidence support the effectiveness of IPE among health sciences' undergraduate students. Because of the volume of the existing literature, we focused on articles describing the benefits and challenges of IPE, individual and organizational barriers to IPE, and faculty development. Researchers have looked at barriers to learning between health and social practitioners (Barr, Hammick, Koppel, \& Reeves, 1999; Barrett, Curran, Glynn, \& Goodwin, 2007; D’Amour \& Oandasan, 2005; Gilbert, 2005b; Robben et al., 2012). Others have examined educators' perceptions of their role adequacy as facilitators of interprofessional learning (Derbyshire, Machin, \& Crozier, 2015; Gilbert, 2005a).

\section{Benefits of Interprofessional Health Education}

There is evidence of positive learning outcomes in the literature. Role clarification (Solomon et al., 2010), enhancement of problem solving skills and clinical decision-making 
(Lapkin, Levett-Jones, \& Gilligan, 2013), increased quality of care (Wilcock, Janes, \& Chambers, 2009), and improved patient safety (Anderson, Thorpe, Heney, \& Petersen, 2009; Kyrkjebø et al., 2006) have been documented. IPE is correlated with positive changes in "attitudes, awareness, and knowledge" among health sciences students (Reeves et al., 2011, p. 171). Using Kirkpatrick's model of changes, Barr et al. (1999) established a taxonomy of anticipated outcomes of IPE. Barr et al. (1999) outlined four levels in which IPE can induce changes: 1) Reaction (changes in attitude toward IPE), 2) learning (knowledge/skills generation and acquisition), 3) behavioural change (transfer of learning), and 4) organization/practice change (structural level). A recent study showed that students in medicine, nursing, and pharmacy, who took part in an interprofessional communication course, reported improvements in "selfconfidence in their communication skills across all 3 colleges" (Hagemeier, Hess, Hagen, \& Sorah, 2014, p. 5). IPE is associated with the development of ethically responsible decisionmaking (Yarborough, Jones, Cyr, Phillips, \& Stelzner, 2000) and problem-solving skills (Borrego et al., 2000), communication efficiency (Solomon \& Salfi, 2011), and increased understanding of the roles of diverse health professionals (Tashiro, Byrne, Kitchen, Vogel, \& Bianco, 2011).

On an experiential level, a majority of students viewed their participation in IPE positively. Results indicate that IPE maximizes opportunities for students to learn in small groups in safe pedagogical environments (Dando, D'Avray, Colman, Hoy, \& Todd, 2012; Mellor, Cottrell, \& Moran, 2013; Salvatori, Berry, \& Eva, 2007; Shiyanbola \& Lammers, 2012; Shiyanbola, Randall, Lammers, Hegge, \& Anderson, 2014; Solomon et al., 2010). IPE develops the trusting relations necessary to build collaborative practice and support students' and faculty's socialization to different philosophies of teaching and learning. For instance, the University of British Columbia's Interprofessional Normal Labour and Birth Workshop (Saxell, Harris, \& Elarar, 2009) and the University of Toronto/St. Michael's Hospital's Intrapartum Workshop (Meffe et al., 2012) represent examples of successful IPE practicum. These workshops facilitated teamwork, built secure communication between students and teachers and scholars, and supported a willingness to collaborate to provide women with high-quality care. Problem-based learning, small group discussions, and online exercises were the means of delivery which made IPE very attractive to the students (Hoffman, Rosenfield, \& Nasmith, 2009; Salfi, Solomon, Allen, Mohaupt, \& Patterson, 2012). IPE provided students with competencies to support collaborative practice in academic and community settings (Proctor et al., 2010; Racine, Proctor, \& Jewell, 2012). These competencies can be extended to health sciences faculty. Interprofessional teaching reinforces the relationships necessary for building faculty's confidence and supporting collaborative teaching (Sinfield, Donoghue, Horobin, \& Anderson, 2012). Interprofessional teaching answers the need for diverse faculty members to learn together (D'Eon, 2005; Steinert, 2005), and the transfer of knowledge from academic to clinical settings (Ho et al., 2008; Simmons et al., 2011). Although positive learning outcomes among health sciences students abound, the implementation of IPE is not without raising some organizational and individual challenges.

\section{Challenges of Interprofessional Health Education}

Organizational barriers involve structural or governance issues at the level of the university or the clinical settings. IPE creates the need to develop an infrastructure to coordinate the schedules of a variety of students and teachers (Ho et al., 2008). There is a need to harmonize different curricula and timetables while creating an academic culture that values interprofessionality. Adequate funding, support of university leaders, incentives to teach 
interprofessionally, and faculty readiness are critical conditions of success (Steinert, 2005). The lack of incentives to teach with an IPE environment and the lack of protected time to develop curricula present major hurdles to the implementation of IPE.

The lack of leadership translates into another obstacle to implementing IPE (Pfaff et al., 2013). Bennett, Gum, Lindeman, and Lawn (2011) reported that "leadership and commitment at the executive level were fundamental to IPE success" (p. 573). Laissez-faire attitudes of senior executives and deans illustrate a lack of organizational commitment. Steinert (2005) found that the lack of leadership was a critical barrier to the development, implementation, and sustainability of IPE in universities and clinical settings.

Individual challenges arise from personal beliefs or attitudes about IPE. The lack of faculty members' knowledge and skills to design interprofessional courses and to teach collaboratively presents two major individual barriers to IPE implementation (Ho et al., 2008). Steinert (2005) underlined that a majority of faculty members have not been trained in an interprofessional environment and may lack the knowledge to apply the principles of IPE. Negative attitudes or stereotypes towards other health professions are associated with gender, social status, prior knowledge of IPE, "silo" approaches to teaching, and professional culture. Negative stereotypes still present significant barriers to collaboration, and researchers insist on the need to address power relations between health professionals (Ateah et al. 2011; Hart, 2015). For example, Curran, Sergeant, and Hollett (2007) reported that men scored significantly lower on their attitude score than did females, suggesting that gender plays a role in an individual's attitudes toward IPE. Curran et al. (2007) revealed that medical faculty had a significantly lower mean score than that of their nursing counterparts. Lash et al. (2014) found that faculty from medicine had lower opinion scores of perceived support for IPE when compared to the scores of colleagues of pharmacy and physician assistant programs. Lower results among medical faculty explain why learning and teaching with nursing and other health faculty members is an important strategy for addressing stereotypes. Negative stereotypes affect perceptions of academic ability, professional competence, and autonomy (Ateah et al., 2011). Ateah et al. reported that students' short immersions in IPE academic and clinical activities were "sufficient to provide significant positive alternations to health care education students' perceptions of various health professions" (2011, p. 212). Although these findings cannot be applied to faculty members, it may be hypothesized that IPE exposure and immersion are likely to bring about changes among health sciences faculty.

\section{Faculty Development}

Faculty development refers to "activities designed to help educations in all settings to teach in a more efficient and satisfactory manner and promote organizational change and development" (Steinert, 2005, p. 61). For Steinert, teacher effectiveness is the ultimate goal of faculty development activities. Faculty development approaches help the teachers gain knowledge and pedagogic skills to teach within an IPE environment. In a meta-analysis of 89 general publications on IPE, Abu-Rish et al. (2012) found that $81.9 \%(n=68)$ did not describe where faculty acquire their skills to teach interprofessionally. These same authors reported that only $18 \%(\mathrm{n}=15)$ of the studies documented faculty preparation strategies. Steinert (2005) indicated that successful implementation of IPE largely depends on faculty development programs, yet the literature shows a dearth of evidence on faculty development. Abu-Rish et al.'s results reveal the scarcity of empirical work on interprofessional faculty development programs in health sciences. 


\section{Methods}

A cross-sectional survey incorporating closed and a few open-ended qualitative questions were our choice to explore the following research questions:

1) What are the faculty's needs in the development and implementation of IPE

2) What are the facilitators and barriers to implementing IPE?

3) What is the level of readiness of faculty members to incorporate IPE in their teaching?

Ethical approval was secured from the Behavioural Ethics Board Committee of the University of Saskatchewan before starting data collection. Participation in the study was voluntary and confidential. Completion of the survey was considered as a provision of informed consent to participate. The online administration of the survey enabled us to maintain participants' confidentiality and anonymity. Faculty did not receive any incentive beyond the knowledge that their input would be used to develop an evidence-based faculty development plan to support IPE.

Recruitment occurred through an email invitation sent to all faculty members in the College of Nursing. The only criterion for taking part in the study was to be a faculty member in the College of Nursing at the time of the research and did not consider tenure, geographical site, or employment status (tenured/non-tenured, limited, full-time, or professoriate/clinical instructors). A letter of invitation to participate in the study was emailed to all faculty meeting the criterion of inclusion $(n=53)$. The survey was uploaded and posted online with the support of our internet technology team. Participants were able to access the questionnaire through a hyperlink.

\section{Development of the Survey}

Items were sampled and generated from the National Interprofessional Competency Framework (Canadian Interprofessional Health Collaborative [CIHC], 2010). A review of the Canadian framework for interprofessional competencies helped us to develop items to assess the following five competencies:

1) Demographic information (5 items)

2) Knowledge of IPE (28 items)

3) Perceptions of IPE (22 items)

4) Beliefs related to IPE (10 items)

5) Barriers to IPE (3 items)

Other items were derived from the McFadyen, Maclaren, and Webster's Interdisciplinary Education Perception Scale (2007). The IEPS is highly reliable as demonstrated by a Cronbach's alpha of greater than 0.80 and "achieve[s] or approach[s] the 0.60 level for sub-scale total testretest reliability" (McFadyen et al., p. 440). The survey included a total number of 68 items on a 6-point Likert-type scale. Each section consisted of items such as "how would you rate your skill level in integrating IPE into your teaching? ( $1=$ not proficient; $6=$ extremely proficient), as well as text boxes to include comments.

Face validity, content validity, and internal consistency were tested. Face validity "refers to whether the instrument looks as though measuring the appropriate construct" (Polit \& Beck, 2008 , p. 458). Content validity indicates if the instrument has "an appropriate sample of items for the construct to be adequately measured" (Polit \& Beck, 2008, p. 458). Content validity was 
assessed by a group of three independent experts in health and IPE. Their expert status was recognized by holding a doctorate in education or health sciences and having interprofessional teaching experience. Drawing on the IEPS scale (McFadyen et al., 2007) and the National Interprofessional Competency Framework (CIHC, 2010) increased the content validity by ensuring the sampling of IPE competencies. Experts did not propose any modifications, and the survey was judged to be valid. The survey was pre-tested by three faculty members not participating in the research and working in different health science colleges. The pre-test allowed for testing the length of completion of the survey and addressing any vague statements related to the items. No item was modified after the pre-test.

Internal consistency of the scale was in tested and resulted in a coefficient alpha or Cronbach's alpha of .943, suggesting high homogeneity among the total item in measuring domains of IPE. Multiple response items were analyzed using the multiple response functions in SPSS $^{\mathrm{TM}}$ version 20 . We can safely argue that the survey met the requirements of the face validity, content validity, and internal consistency. Further analyses to confirm construct validity of the instrument are required, but the questionnaire was valid for achieving the goals of the pilot study.

\section{Data Collection}

The survey was administered over a four-week period from August to September 2013. As a part of best practices for conducting an online survey, an email reminder was sent to all faculty two weeks after the original posting (Dillman, Smyth, \& Christian, 2000). In total, 20 faculty members out of 53 participated in the survey. All participants were female. The modal category shows that a majority of participants (70\%) ranged in age from 41 to 60 years. Fifty-five percent $(55 \%)$ of the participants indicated they were either tenured or in a tenure-track position. This low participation rate $(35 \%)$ may relate to the fact that the researchers were colleagues, that one researcher is an academic administrator, or a lack of interest.

Table 1

Demographics of the Sample (Frequency Distribution)

\begin{tabular}{lcc}
\hline Age range & $\begin{array}{c}\text { Age } \\
\text { Frequency (n) }\end{array}$ & Percent \\
\hline $31-40$ & 3 & $15 \%$ \\
$41-50$ & 6 & $30 \%$ \\
$51-60$ & 8 & $40 \%$ \\
$61-70$ & 3 & $15 \%$ \\
\hline & Faculty Position \\
Position & Frequency (n) & Percent \\
\hline Full Time & 10 & $34 \%$ \\
Part Time & 1 & $3.4 \%$ \\
Limited Term & 4 & $13.8 \%$ \\
Not Tenured & 3 & $10.3 \%$ \\
Tenured & 8 & $27.6 \%$ \\
Tenure Track & 3 & $10.3 \%$
\end{tabular}




\begin{tabular}{lcc}
\hline & Years at University & \\
Year Category & Frequency $(\mathrm{n})$ & Percent \\
\hline 0-5 years & 4 & $20 \%$ \\
6-10 years & 4 & $20 \%$ \\
11-15 years & 5 & $25 \%$ \\
16-20 years & 3 & $15 \%$ \\
26-30 years & 2 & $10 \%$ \\
$31+$ years & 2 & $10 \%$
\end{tabular}

\section{Data Analysis}

The quantitative data were analyzed in SPSSTM version 20. Descriptive statistics was used to analyze demographic variables. According to Knapp (1990) and Dawes (2008), the use of ordinal data as interval data is problematic and may result in the loss of power in statistical analysis. However, Pett (1997) argues that a large sample can minimize the limitations of ordinal variables. Based on these elements, non-parametric statistics was used due to small sample size $(n=20)$ and the ordinal level of measurement of the data. A level of significance of .05 was selected to perform statistical analyses. The use of the Pearson correlation coefficient is not recommended in the case of non-continuous variables and non-linearity (Allen \& Yen, 1979). Spearman's rho is a robust non-parametric test to run in small samples. Spearman's rho was used to identify correlations among all ordinal items. A correlation coefficient close to +1 or -1 represents the magnitude or the strength of the association between variables (Allen \& Yen, 1979).

Qualitative data was collected from the survey's comments boxes and analyzed manually. The survey included a few short open-ended questions to invite further clarification. For instance, "Have you had prior experience with IPE?" "Can you describe?" Thorne's interpretive description approach to data coding was used to make sense of the qualitative comments (Thorne, 2008). In vivo codes were created and regrouped into categories. In vivo codes emerge from the data through inductive analysis. This approach to data analysis aligns with the tenets of interpretive description where data coding focuses on themes and ideas rather than on fracturing the data word by word (Thorne, 2008). Interpretive description avoids data forcing by facilitating the process of emergence. Emergence and induction represent the hallmarks of qualitative data analysis. Data saturation was not achieved because of the short comments inherent to exploratory surveys. Participants' quotations were used to support or contrast the quantitative findings.

\section{Results}

\section{Quantitative Findings}

The majority of participants reported their level of familiarity with different domains of IPE. The survey included the six domains of interprofessional knowledge as proposed by the National Interprofessional Competency Framework (CIHC, 2010). Participants were asked to rank their level of familiarity on a 6-point scale varying from 1 "unfamiliar" to 6 "very familiar." The following are the percentages of participants that responded with a 5 (familiar) or 6 (very familiar) for each domain of IPE knowledge: Interprofessional communication (65\%), patient/client/family care (80\%), role clarification $(60 \%)$, team functioning $(55 \%)$, collaborative leadership (55\%), and conflict resolution (40\%). While participants reported a high level of 
familiarity with patient/client/family care, they were less familiar with the other competencies. This result suggests further faculty development and education on the competencies to apply IPE in their teaching activities is warranted.

\section{Demographic Data}

Age showed no significant correlation with any items from any subsection, except for the number of years at university $(.718 ; \mathrm{p}<=0.01))$. The number of years a faculty member was at the university was significantly correlated with two statements: 1) "Shared teaching will help me to understand my limitations" $(.583 ; \mathrm{p}<=0.01)$, and 2$)$ "Individuals in my college are very positive about their contribution toward IPE" $\left(.635^{* *} ; \mathrm{p}<=0.01\right)$.

\section{Knowledge of IPE}

When asked if they had prior experience with IPE, 70\% (n=14) responded "yes" while $30 \%(\mathrm{n}=6)$ responded "no." It is interesting to note that of the total number of participants, $90 \%$ $(n=18)$ said they have applied it in their teaching, despite only $70 \%(n=14)$ indicating prior experience. It is possible that some participants misinterpreted the question of "prior experiences" to mean experiences, not including the experience of teaching it themselves. Of those who reported having incorporated IPE in their teaching, 50\% $(\mathrm{n}=10)$ responded that they applied it "often." Although 70\% ( $\mathrm{n}=14)$ indicated that they felt prepared to incorporate IPE into their teaching, only $50 \%$ believed their skill level in integrating IPE was "good" $(45 \%$; $n=9)$ or excellent $(5 \% ; \mathrm{n}=1)$. The remainder rated their skill level as "average" $(35 \% ; \mathrm{n}=7)$, fair $(5 \%$; $\mathrm{n}=1)$, or poor $(10 \% ; \mathrm{n}=2)$. Participants were asked to rank which areas of study that they felt would be most suited to IPE (clinical, theory, or non-nursing areas of health). Based on the responses, clinical was perceived as the most suitable area (52.8\%), followed by theory (27.8\%), and then non-nursing areas in health $(19.4 \%)$. Participants were asked to select from a number of content courses (e.g., mental health, communication, rural study, medical surgery, pediatrics, community, leadership, research, other) that they believed best lent themselves to IPE. They were allowed to select multiple course contents. The responses were equally divided between mental health and rural education (for both items, 90\% of participants indicated those areas were suited to IPE. The items that received the least positive responses were medical surgery, pediatrics, and leadership (all three items received a $65 \%$ positive response).

\section{Perceptions and Beliefs about IPE}

The questionnaire also included 31 items related to perceptions of IPE drawn from McFadyen et al.'s. (2007) Interdisciplinary Education Perception Scale (IEPS). Participants were asked to indicate their level of agreement on a 5 -point scale (1=strongly disagree; $2=$ disagree; $3=$ =neutral; $4=$ agree; $5=$ strongly agree). These responses were collapsed into disagreeing, neutral, and agreeing. The statement that had the highest percentage of participants in agreement $(95 \%$; $\mathrm{n}=19$ ) was "IPE is essential for team-working skills." Two statements had a large proportion $(80 \% ; \mathrm{n}=16)$ of disagreement from participants: "Clinical problem-solving skills can only be taught by faculty from my discipline" and "Individuals in my college have a higher status than individuals in other colleges." Most participants (70\%) indicated that they would like their IPE learning needs to be met through a workshop. 
Table 2

Perceptions of IPE $(n=20)$

\begin{tabular}{|c|c|c|c|c|c|c|c|}
\hline & $\begin{array}{l}\text { Strongly } \\
\text { Disagree }\end{array}$ & Disagree & Neutral & Agree & $\begin{array}{c}\text { Strongly } \\
\text { Agree }\end{array}$ & Mean & Mode \\
\hline Individuals in my college are & $n=3$ & $\mathrm{n}=4$ & $\mathrm{n}=10$ & $\mathrm{n}=2$ & $\mathrm{n}=1$ & & \\
\hline well-trained in IPE & $15 \%$ & $20 \%$ & $50 \%$ & $10 \%$ & $5 \%$ & 3.30 & 3 \\
\hline Able to work closely with & $\mathrm{n}=2$ & $\mathrm{n}=1$ & $\mathrm{n}=7$ & $\mathrm{n}=8$ & $\mathrm{n}=2$ & & \\
\hline individuals in other professions & $10 \%$ & $5 \%$ & $35 \%$ & $40 \%$ & $10 \%$ & 2.65 & 2 \\
\hline Demonstrate a great deal of & $\mathrm{n}=1$ & $\mathrm{n}=2$ & $\mathrm{n}=2$ & $\mathrm{n}=13$ & $\mathrm{n}=2$ & 225 & \\
\hline autonomy & $5 \%$ & $10 \%$ & $10 \%$ & $\mathrm{n}=65 \%$ & $10 \%$ & 2.33 & 2 \\
\hline Respect the work done by & $\mathrm{n}=2$ & $\mathrm{n}=4$ & $\mathrm{n}=6$ & $\mathrm{n}=7$ & $\mathrm{n}=1$ & 295 & 2 \\
\hline individuals in my college & $10 \%$ & $20 \%$ & $30 \%$ & $35 \%$ & $5 \%$ & 2.95 & 2 \\
\hline Are very positive about the goals & $\mathrm{n}=3$ & $\mathrm{n}=7$ & $\mathrm{n}=7$ & $\mathrm{n}=1$ & $\mathrm{n}=2$ & 340 & $3 *$ \\
\hline and objectives of IPE & $15 \%$ & $35 \%$ & $35 \%$ & $5 \%$ & $10 \%$ & 3.40 & $3^{n}$ \\
\hline $\begin{array}{l}\text { Need to cooperate with other } \\
\text { colleges }\end{array}$ & -- & -- & $\begin{array}{l}\mathrm{n}=6 \\
30 \%\end{array}$ & $\begin{array}{l}\mathrm{n}=7 \\
35 \%\end{array}$ & $\begin{array}{l}\mathrm{n}=7 \\
35 \%\end{array}$ & 1.95 & $1^{*}$ \\
\hline $\begin{array}{l}\text { Are very positive about their } \\
\text { contribution toward IPE }\end{array}$ & $\begin{array}{l}\mathrm{n}=1 \\
5 \%\end{array}$ & $\begin{array}{l}\mathrm{n}=2 \\
10 \%\end{array}$ & $\begin{array}{l}n=13 \\
65 \%\end{array}$ & $\begin{array}{l}\mathrm{n}=1 \\
5 \%\end{array}$ & $\begin{array}{l}\mathrm{n}=2 \\
10 \%\end{array}$ & 2.95 & 3 \\
\hline $\begin{array}{l}\text { Must depend upon the work of } \\
\text { people in other colleges }\end{array}$ & $\begin{array}{l}\mathrm{n}=3 \\
15 \%\end{array}$ & $\begin{array}{l}\mathrm{n}=10 \\
50 \%\end{array}$ & $\begin{array}{l}\mathrm{n}=5 \\
25 \%\end{array}$ & $\begin{array}{l}\mathrm{n}=1 \\
5 \%\end{array}$ & $\begin{array}{l}\mathrm{n}=1 \\
5 \%\end{array}$ & 3.65 & 4 \\
\hline $\begin{array}{l}\text { Other colleges think highly of my } \\
\text { college }\end{array}$ & $\begin{array}{l}\mathrm{n}=1 \\
5 \%\end{array}$ & $\begin{array}{l}\mathrm{n}=5 \\
25 \%\end{array}$ & $\begin{array}{l}\mathrm{n}=7 \\
35 \%\end{array}$ & $\begin{array}{l}\mathrm{n}=5 \\
25 \%\end{array}$ & $\begin{array}{l}\mathrm{n}=2 \\
10 \%\end{array}$ & 2.90 & 3 \\
\hline $\begin{array}{l}\text { Have a higher status than } \\
\text { individuals in other colleges }\end{array}$ & $\begin{array}{l}\mathrm{n}=7 \\
35 \%\end{array}$ & $\begin{array}{l}\mathrm{n}=9 \\
45 \%\end{array}$ & $\begin{array}{l}\mathrm{n}=4 \\
20 \%\end{array}$ & -- & -- & 4.15 & 4 \\
\hline $\begin{array}{l}\text { Make every effort to understand } \\
\text { the capabilities and contribution } \\
\text { of other colleges }\end{array}$ & $\begin{array}{l}\mathrm{n}=3 \\
15 \%\end{array}$ & $\begin{array}{l}\mathrm{n}=6 \\
30 \%\end{array}$ & $\begin{array}{l}\mathrm{n}=6 \\
30 \%\end{array}$ & $\begin{array}{l}\mathrm{n}=4 \\
20 \%\end{array}$ & $\begin{array}{l}\mathrm{n}=1 \\
5 \%\end{array}$ & 3.30 & $3 *$ \\
\hline Are extremely competent in IPE & $\begin{array}{l}\mathrm{n}=3 \\
15 \%\end{array}$ & $\begin{array}{l}\mathrm{n}=7 \\
35 \%\end{array}$ & $\begin{array}{l}\mathrm{n}=6 \\
30 \%\end{array}$ & $\begin{array}{l}\mathrm{n}=2 \\
10 \%\end{array}$ & $\begin{array}{l}\mathrm{n}=1 \\
5 \%\end{array}$ & 3.47 & 4 \\
\hline $\begin{array}{l}\text { Are willing to share information } \\
\text { and resources with other colleges }\end{array}$ & $\begin{array}{l}\mathrm{n}=2 \\
10 \%\end{array}$ & $\begin{array}{l}\mathrm{n}=4 \\
20 \%\end{array}$ & $\begin{array}{l}\mathrm{n}=5 \\
25 \%\end{array}$ & $\begin{array}{l}\mathrm{n}=8 \\
40 \%\end{array}$ & $\begin{array}{l}\mathrm{n}=1 \\
5 \%\end{array}$ & 2.90 & 2 \\
\hline $\begin{array}{l}\text { Have good relations with people } \\
\text { in other colleges }\end{array}$ & $\begin{array}{l}\mathrm{n}=2 \\
10 \%\end{array}$ & -- & $\begin{array}{l}\mathrm{n}=8 \\
40 \%\end{array}$ & $\begin{array}{l}\mathrm{n}=8 \\
40 \%\end{array}$ & $\begin{array}{l}\mathrm{n}=2 \\
10 \%\end{array}$ & 2.60 & $2 *$ \\
\hline $\begin{array}{l}\text { Think highly of other related } \\
\text { colleges }\end{array}$ & $\begin{array}{l}\mathrm{n}=1 \\
5 \%\end{array}$ & $\begin{array}{l}\mathrm{n}=1 \\
5 \%\end{array}$ & $\begin{array}{l}\mathrm{n}=9 \\
45 \%\end{array}$ & $\begin{array}{l}\mathrm{n}=8 \\
40 \%\end{array}$ & $\begin{array}{l}\mathrm{n}=1 \\
5 \%\end{array}$ & 2.65 & 3 \\
\hline Work well with each other & $\begin{array}{l}\mathrm{n}=4 \\
20 \%\end{array}$ & $\begin{array}{l}\mathrm{n}=4 \\
20 \%\end{array}$ & $\begin{array}{l}\mathrm{n}=7 \\
35 \%\end{array}$ & $\begin{array}{l}\mathrm{n}=3 \\
15 \%\end{array}$ & $\begin{array}{l}\mathrm{n}=1 \\
5 \%\end{array}$ & 3.37 & 3 \\
\hline $\begin{array}{l}\text { Other colleges often seek the } \\
\text { advice of people in my college }\end{array}$ & $\begin{array}{l}\mathrm{n}=1 \\
5 \%\end{array}$ & -- & $\begin{array}{l}n=12 \\
60 \%\end{array}$ & $\begin{array}{l}\mathrm{n}=6 \\
30 \%\end{array}$ & $\begin{array}{l}\mathrm{n}=1 \\
5 \%\end{array}$ & 2.70 & 3 \\
\hline
\end{tabular}

Agreements with the statement "I believe that IPE is the basis for quality improvement" was significantly related $(.829 ; \mathrm{p}<=0.01)$ with responses indicating a high level of knowledge about collaborative leadership. Additionally, there was a strong positive association (.807; $\mathrm{p}<=0.01)$ with the statement "Individuals in my college can work closely with individuals in other professions" and "Individuals in my college are extremely competent in IPE." Another strong significant positive correlation manifested in the responses to the question "I believe the College of Nursing is making an adequate effort to promote IPE" and "Individuals in my college are extremely competent in IPE" $(.742 ; \mathrm{p}<=0.01)$. Several items significantly correlated among the different subsections, particularly among the Knowledge and Beliefs subsections. 


\section{Table 3}

Perceptions of Interprofessional Communication, Patient Centered-Care, Team Functioning, Collaborative Leadership, and Conflict Resolution $(n=20)$

\begin{tabular}{|c|c|c|c|c|c|c|}
\hline & $\begin{array}{c}\text { Inter- } \\
\text { professional } \\
\text { Communication }\end{array}$ & $\begin{array}{l}\text { Patient } \\
\text { Centered } \\
\text { Care }\end{array}$ & $\begin{array}{c}\text { Role } \\
\text { Clarification }\end{array}$ & $\begin{array}{c}\text { Team } \\
\text { Functioning }\end{array}$ & $\begin{array}{l}\text { Collaborative } \\
\text { Leadership }\end{array}$ & $\begin{array}{l}\text { Conflict } \\
\text { Resolution }\end{array}$ \\
\hline $\begin{array}{l}\text { I would welcome the } \\
\text { opportunity to work on } \\
\text { curriculums with faculty } \\
\text { from other colleges }\end{array}$ & $.631 * *$ & 0.260 & $.710 * *$ & $.659 * *$ & $.589 * *$ & $.642 * *$ \\
\hline $\begin{array}{l}\text { I must acquire more } \\
\text { knowledge of IPE than } \\
\text { faculty from other colleges }\end{array}$ & $-.558^{*}$ & -0.431 & $-.627 * *$ & $-.644 * *$ & $-.490 *$ & $-.708 * *$ \\
\hline $\begin{array}{l}\text { Individuals in my college } \\
\text { need to cooperate with other } \\
\text { colleges }\end{array}$ & $.588 * *$ & $.745^{* *}$ & $.487 * *$ & $.514 *$ & $.573 * *$ & 0.389 \\
\hline $\begin{array}{l}\text { I believe IPE has positive } \\
\text { outcomes for practice }\end{array}$ & $.736 * *$ & $.512 *$ & $.657 * *$ & $.696^{* *}$ & $.730 * *$ & $.557 *$ \\
\hline $\begin{array}{l}\text { I believe that IPE will } \\
\text { promote health outcomes } \\
\text { among patients }\end{array}$ & $.662 * *$ & $.600 * *$ & $.679 * *$ & $.653 * *$ & $.652 * *$ & $.747 * *$ \\
\hline $\begin{array}{l}\text { I am unsure of my role in } \\
\text { IPE }\end{array}$ & $-.632 * *$ & -0.27 & $-.504 *$ & $-.643 * *$ & $-.671^{* *}$ & $-.581 * *$ \\
\hline $\begin{array}{l}\text { Individuals in my college } \\
\text { need to cooperate with other } \\
\text { colleges }\end{array}$ & $.588 * *$ & $.745 * *$ & $.487 *$ & $.514 *$ & $.573 * *$ & 0.389 \\
\hline $\begin{array}{l}\text { Communication skills } \\
\text { should be taught with } \\
\text { faculty from other colleges }\end{array}$ & $.546^{*}$ & $.488 *$ & $.592 * *$ & $.557 *$ & $.573 * *$ & $.639 * *$ \\
\hline $\begin{array}{l}\text { Students will ultimately } \\
\text { benefit if faculty from } \\
\text { different colleges teach } \\
\text { collaboratively }\end{array}$ & $.595 * *$ & $.613 * *$ & 0.397 & $.480 *$ & $.713 * *$ & $.573 * *$ \\
\hline $\begin{array}{l}\text { To teach IPE effectively, } \\
\text { team-working skills are } \\
\text { essential for all health care } \\
\text { faculty }\end{array}$ & $.573 * *$ & $.513^{*}$ & 0.424 & $.503 *$ & $.590 * *$ & $.596 * *$ \\
\hline
\end{tabular}

Note: *Correlation is significant at the 0.05 level (2-tailed)

**Correlation is significant at the 0.01 level (2-tailed). 


\section{Perceived Barriers to Implementing IPE}

When asked what barriers they had encountered in implementing IPE, $75 \%$ said timetable. Many (68.6\%) also reported that a heavy workload was an obstacle to implementing IPE into their teaching. Table 4 provides a breakdown of which barriers participants found the most salient.

Table 4

Frequency Distribution of the Barriers to IPE

\begin{tabular}{lcc}
\hline Type of Barrier & Frequency (n) & Percentage \\
\hline Lack of Leadership & 6 & $5.7 \%$ \\
Political tension & 4 & $3.8 \%$ \\
Resistance to change & 8 & $7.5 \%$ \\
Timetable & 12 & $11.3 \%$ \\
Class sizes & 6 & $5.7 \%$ \\
Curriculum & 6 & $5.7 \%$ \\
Accreditation & 1 & $0.9 \%$ \\
Workload & 11 & $10.4 \%$ \\
Lack of knowledge & 9 & $8.5 \%$ \\
Lack of time with existing IPE activities & 9 & $8.5 \%$ \\
Lack of time to develop new IPE activities & 9 & $8.5 \%$ \\
Lack of interest & 4 & $3.8 \%$ \\
Lack of pedagogical support & 5 & $4.7 \%$ \\
Lack of technological support & 5 & $4.7 \%$ \\
Consuming logistics to coordinate & 11 & $10.4 \%$
\end{tabular}

In general, results indicate that participants perceived that the incorporation of IPE into their courses is not only beneficial but essential for the enhancement of teamwork skills. When asked to rate the degree to which they value the incorporation of IPE into nursing, 45\% ( $n=9)$ responded they found it "extremely valuable." Only one participant (5\%) reported that it was not of value while the remainder of participants rated the level of value between extremely valuable and not valuable. The qualitative data revealed possible explanations for that IPE was seen as less valuable for some participants, such as time constraints: "I feel as it is another thing to do requiring a lot of time with minimal rewards for faculty." The scheduling of IPE into an already full course ( 4 or 5 courses) workload is a challenge for many faculty members. Not only was "timetable" the most frequently reported barrier, but scheduling was listed as "the most commonly reported barrier to IPE implementation" in $47 \%$ of the studies reviewed by Abu-Rish's et al. (2012). To alleviate this obstacle, courses specifically dedicated to IPE may be more useful than teaching IPE as a subtopic or component within other courses. One participant mentioned:

I think we need to have someone designated to initiate and organize interprofessional education. Saying we are going to do it does not get it done. I think we should start small and perhaps do lab experiences in an IPE fashion.

Another important finding is that although many faculty members already incorporate IPE in their courses, comparatively few perceive their skill level as above average. This lack of readiness can be related to some confusion about what IPE is and how to apply pedagogical principles related to teaching IPE. For instance, a participant mentioned: "A clear definition is lacking as to what IPE means and what teaching methodologies encompass this philosophy." 
Many geographical sites may become a logistic problem that affects participants' readiness to implement IPE. Another participant underlined: "I am open to the idea of IPE; however, having numerous sites and different availability of disciplines at each location, it makes it very difficult to attain." Finally, lack of readiness may also be associated with organizational factors. A participant noted: "It is a worthy goal, but one difficult to implement because of the lack of interprofessional administrative support in aligning appropriate courses for IPE among relevant colleges." The perceived or real lack of administrative support negatively influences faculty's readiness to teach within an IPE context.

\section{Discussion}

Our pilot study proposed to identify the faculty's needs for faculty development, explore the faculty's knowledge of IPE, assess faculty readiness to apply IPE within their teaching, and understand perceived barriers and beliefs to successful IPE implementation.

\section{Faculty's Knowledge Needs}

The findings suggest that faculty members have unmet needs before they are able to teach IPE content with confidence. These unmet needs relate to faculty's lack of knowledge of IPE and how to integrate this content into their courses. Similarly, the need to know the pedagogic principles to teach in an interprofessional context is delineated. These findings are consistent with the results obtained in Barr et al.'s study (2011) as reported:

Most university and practice teachers lacked the firsthand experience of interprofessional training from their student days and hence facilitation; many lacked confidence; some were anxious about working with students with a different body of knowledge and being expected to answer questions beyond the purview of their profession. (p. 39)

Participants' lack of readiness to implement IPE relates to the lack of knowledge and fears of being out of their disciplinary field. Barr et al. (2011) underlined the need to implement faculty development strategies to empower faculty and provide them with the pedagogical knowledge and the facilitation skills to assist interprofessional teaching. Knowledge of facilitation skills and pedagogical approaches is likely to stimulate faculty's readiness to participate in IPE activities. This finding aligns with Curran, Sharpe, and Forristall (2007) who reported that participants who had a prior history of IPE scored significantly higher than those without. Preparing faculty for interprofessional teaching also requires removing institutional/organizational barriers affecting the effectiveness of interprofessional endeavours.

\section{Organizational Barriers}

The barriers to implementing interprofessional health education, especially time constraints and logistics problems, are still present. Time constraints reflect a need for structural reorganization. Addressing time limitations and logistics issues is likely to increase faculty's readiness to participate in IEP activities. Steinert (2005) underlines the need to provide faculty with incentives such as time release to learn and apply IPE pedagogy in interprofessional courses designs. Pfaff et al. (2013) indicate that IPE does not occur in a void but within a political, economic, and social context. Also, our results align with the findings of previous research showing that organizational support represents a key factor to facilitate the implementation of IPE and support faculty members (Lawlis, Anson, \& Greenfield, 2014).

Another organizational barrier arises from the lack of common understanding of IPE

among health faculties. The lack of mutual understanding is not without the creation of problems 
in designing interprofessional academic and clinical activities. Derbyshire et al. (2015) emphasize the importance of role clarity as a pre-requisite for creating a culture of interprofessionality in academic health sciences. Barr et al. (2011) mentioned that bringing teachers together to provide an IPE health curriculum may be a daunting task, considering that health professionals usually work in entrepreneurial and autonomous practice and merely know about each other's courses. Working and learning together are mandatory conditions to implement IPE, as "without a concerted effort to educate health care professionals with and about each other, it is unlikely that such [IPE] teams can function effectively" (Ateach et al., 2011, p. 213). This matter delves into our next theme relating to individual barriers to interprofessional health education.

\section{Individual Barriers}

Results indicate that interprofessional health education remains sensitive to professional turf wars among healthcare disciplines. A complex nexus of power relations intersects with gender and the social prestige of one's profession to create personal barriers. For instance, our participants' perceptions of lower disciplinary status indicate that power relations play a significant role within universities. Low self-esteem may explain why the majority of participants disagreed with the statement "Individuals in my college have a higher status than individuals in other colleges." This statement indicates that medicine continues to be associated with a higher professional and social status. Devaluation of one's profession compared to physicians may strongly resonate among nurse educators because of the strong influence of biomedical knowledge in nursing (Hall, 2005). This lack of valorization of nursing is not a new phenomenon per se. Devaluation of nursing aligns with other research studies describing how hierarchical power and strong professional cultures represent major barriers to implementing IPE in health education (Ateah et al. 2011; Ginsberg \& Tregunno, 2005; Suchman, 2006). Ateah et al. (2011) underscore that the view of a nurse as a "jack of all trades" undermines the nursing-specific contributions in practice settings. Hart (2015) suggests addressing nurses' disempowerment through critical empowerment strategies like critical thinking and conflict management activities. Critical empowerment strategies reveal the relations of power within interprofessional teams and help nurses to understand how to manage power dynamics within teams. Consequently, the willingness to integrate IPE in health sciences cannot be achieved without a desire to examine the relations of power that underpin nursing and health education.

Finally, the results align with previous research conducted by Barr et al. (2011) in the PIPE project aimed at preparing UK university professors to develop and apply facilitation skills, interprofessional communication, and understand theoretical models that guide interprofessional teaching. For instance, Barr et al. underline the need to develop teaching and learning activities and prepare the teachers for effective implementation of IPE. Our results are congruent with studies conducted within Canada's IPE for Collaborative Patient-Centred Practice (IECPCP) (Gilbert, 2010). Gilbert (2010) clearly underlines that IPE cannot occur without investment in resources, curriculum changes, structural modifications, and a willingness to learn and apply the principles of IPE. For these changes to occur there is a critical necessity to provide faculty with the knowledge, skills, and time to design and implement interprofessional learning experiences. Gilbert mentions that a successful implementation of IPE "must be applied in a flexible and changeable way that is tailored to the needs of the specific setting, organization or unit" (p. 218). Our results suggest that lack of knowledge about the pedagogical underpinnings of IPE and collaborative teaching affect faculty's level of readiness. Readiness can be improved through the development and implementation of innovative IPE initiatives. For instance, a Canadian study 
revealed that interprofessional shadowing was effective in addressing individual barriers to IPE (Shafran, Richardson, \& Bonta, 2015). Shafran et al. (2015) reported that shadowing other health care professionals helped fourth-year medical students understanding the roles and scope of practice of non-medical health practitioners. Our findings also align with Steinert's findings (2005). Steinert found faculty development strategies must focus on IPE, teaching and learning, and leadership and organizational changes. Faculty development strategies must provide clear answers as to why IPE is important and how to apply it.

\section{Limitations of the Study}

The small sample size represents a limitation of this study. A larger sample size would have ensured generalizability, yet our analyses are based on robust non-parametric tests. Another limitation is the lack of qualitative data from focus groups and individual interviews that may have provided depth to the analysis. In the future, we need to increase the sample size and recruit other health sciences faculty to validate or disconfirm some results about disciplinary status, professional culture, negative perceptions, and perceptions about nursing's lack of prestige.

\section{Conclusion}

This pilot study reveals a lack of faculty development programs in nursing and health education. Results indicate that individual and organizational challenges remain significant issues to address in interprofessional health education. These issues translate into critical needs to design and implement faculty development programs to prepare nursing and health sciences faculty to teach within an IPE academic context. 


\section{References}

Abu-Rish, E., Kim, S., Choe, L., Varpio, L., Malik, E., White, A. A., ... Zierler, B. (2012). Current trends in interprofessional education of health sciences students: A literature review. Journal of Interprofessional Care, 26(6), 444-451. http://dx.doi.org/10.3109/13561820.2012.715604

Allen, M. J., \& Yen, W. M. (1979). Introduction to measurement theory. Monterey, CA: Brooks $\&$ Cole.

Anderson, E., Thorpe, L., Heney, D., \& Petersen, S. (2009). Medical students benefit from learning about patient safety in an interprofessional team. Medical Education, 43(6), 542552.

Ateah, C. A., Snow, W., Wener, P., MacDonald, L., Metge, C., Davis, P., ... Anderson, J. (2011). Stereotyping as a barrier to collaboration: Does IPE make a difference? Nurse Education Today, 31(2), 208-213. http://dx.doi.org/10.1016/j.nedt.2010.06.004

Barr, H., \& Low, H. (2013). Introducing IPE. Fareham, UK: Centre for the Advancement of IPE.

Barr, H., Helme, M., \& D’Avray, L. (2011). Occasional paper No. 12: Developing IPE in health and social care courses in the United Kingdom. London, UK: King's College.

Barr, H., Hammick, M., Koppel, I., \& Reeves, S. (1999). Evaluating interprofessional education: Two systematic reviews for health and social care. British Educational Research Journal, 25(4), 533-544. http://dx.doi.org/10.1080/0141192990250408

Barrett, J., Curran, V., Glynn, L., \& Goodwin, M. (2007). CHSRF synthesis: Interprofessional collaboration and quality primary healthcare. Retrieved from http://www.cfhifcass.ca/Migrated/PDF/SynthesisReport_E_rev4_FINAL.pdf

Bennett, P. N., Gum, L., Lindeman, I., \& Lawn, S. (2011). Faculty perceptions of interprofessional education. Nursing Education Today, 3(6), 571-576. http://dx.doi.org/10.1016/j.nedt.2010.09.008

Bilodeau, K., Dubois, S., \& Pepin, J. (2013). Contributions des sciences infirmières au développement des savoirs interprofessionels. [The contributions of nursing science to interprofessional knowledge development]. Recherche en Soins Infirmiers, 113, 43-50. http://dx.doi.org/10.3917/rsi.113.0043

Borrego, M. E., Rhyne, R., Hansbarger, L. C., Geller, Z., Edwards, P., Griffin, B., ... Scaletti, J.V. (2000). Pharmacy student participation in rural interdisciplinary education using problem-based learning (PBL) case tutorials. American Journal of Pharmacy Education, 64(4), 355-363.

Canadian Interprofessional Health Collaborative. (2010). A national interprofessional competency framework. Retrieved from http://www.cihc.ca/files/CIHC_IPCompetencies_Feb1210.pdf

Côté, G., Lauzon, C., \& Kyd-Strickland, B. (2008). Environmental scan of interprofessional collaborative practice initiatives. Journal of Interprofessional Care, 22(5), 449-460. http://dx.doi.org/10.1080/13561820802210950 
Curran, V. R., Sargeant, J., \& Hollett, A. (2007). Evaluation of an interprofessional continuing professional development initiative in primary health care. Journal of Continuing Education in Health, 27(4), 241-252. http://dx.doi.org/10.1002/chp.144

Curran, V. R., Sharpe, D., \& Forristall, J. (2007). Attitudes of health sciences faculty members towards interprofessional teamwork and education. Medical Education, 41(9), 892-896. http://dx.doi.org/10.1111/j.1365-2923.2007.02823.x

D'Amour, D., \& Oandasan, I. (2005). Interprofessionality as the field of interprofessional practice and IPE: An emerging concept. Journal of Interprofessional Care, 19(Suppl. 1), 8-20. http://dx.doi.org/10.1080/13561820500081604

Dando, N., D’Avray, L., Colman, J., Hoy, A., \& Todd, J. (2012). Evaluation of an interprofessional practice placement in a UK in-patient palliative care unit. Palliative Medicine, 26(2), 178-184. http://dx.doi.org/10.1177/0269216311400479

Dawes, J. G. (2008). Do data characteristics change according to the number of scale points used? An experiment using 5 point, 7 point, and 10 point scales. International Journal of Market Research, 50(1), 1-19. Retrieved from http://papers.ssrn.com/sol3/papers.cfm?abstract_id=2013613

D'Eon, M. (2005). A blueprint for interprofessional learning. Journal of Interprofessional Care, 19(Suppl. 1), 49-59. http://dx.doi.org/10.1080/13561820512331350227

Derbyshire, J. A., Machin, A. I., \& Crozier, S. (2015). Facilitating classroom-based interprofessional learning: A grounded theory study of university educators' perceptions of their role adequacy as facilitators. Nursing Education Today, 35(1), 50-56. http://dx.doi.org/10.1016/j.nedt.2014.05.001

Dillman, D. A., Smyth, J. D., \& Christian, L. M. (2000). Internet, mail, and mixed-mode surveys: The tailored design method (3rd ed.). New York, NY: John Wiley \& Sons.

Gilbert, J. H. V. (2005a). Interprofessional education for collaborative patient-centred practice. Canadian Journal of Nursing Leadership, 18(2), 32-38. http://dx.doi.org/10.12927/cjnl.2005.17181

Gilbert, J. H. V. (2005b). Interprofessional learning and higher education structural barriers. Journal of Interprofessional Care, 19(Suppl. 1), 87-106. http://dx.doi.org/10.1080/13561820500067132

Gilbert, J. H. V. (2010). The status of IPE in Canada. Journal of Allied Health, 39(3), 216-223.

Ginsberg, L., \& Tregunno, D. (2005). New approaches to interprofessional education and collaborative practice: Lessons from the organizational change literature. Journal of Interprofessional Care, 19(Suppl. 1), 177-187. http://dx.doi.org/10.1080/13561820500083105

Hagemeier, N. E., Hess, R., Hagen, K. S., \& Sorah, E. L. (2014). The impact of an interprofessional communication course in nursing, medical, and pharmacy students' communication skill self-efficacy beliefs. American Journal of Pharmacy Education, 78(10), 186-195. http://dx.doi.org/10.5688/ajpe7810186 
Hall, P. (2005). Interprofessional teamwork: Professional cultures as barriers. Journal of Interprofessional care, 19(Suppl. 1), 188-196. http://dx.doi.org/10.1080/13561820500081745

Hart, C. (2015). The elephant in the room: Nursing and nursing power on an interprofessional team. The Journal of Continuing Education in Nursing, 46(8), 349-355. http://dx.doi.org/10.3928/00220124-20150721-01

Ho, K., Jarvis-Selinger, S., Borduas, F., Blye, F., Hall, P., Handfield-Jones, R., ... Rouleau, M. (2008). Making interprofessional education work: The strategic roles of the academy. Academic Medicine, 83(10), 934-940. http://dx.doi.org/10.1097/acm.0b013e3181850a75

Hoffman, S. J., Rosenfield, D., \& Nasmith, L. (2009). What attracts students to interprofessional education and other health care reform initiatives? Journal of Allied Health, 38(3), e75e78.

Knapp, T. H. (1990). Treating ordinal scales as interval scales: An attempt to resolve the controversy. Nursing Research, 39(2), 121-123. http://dx.doi.org/10.1097/00006199199003000-00019

Kyrkjebø, J. M., Brattebø, G., \& Smith-Strøm, H. (2006). Improving patient safety by using interprofessional simulation training in health professional education. Journal of Interprofessional Care, 20(5), 507-516. http://dx.doi.org/10.1080/13561820600918200

Lapkin, S., Levett-Jones, T., \& Gilligan, C. (2013). A systematic review of the effectiveness of IPE in health professional programs. Nurse Education Today, 33(2), 90-102. http://dx.doi.org/10.1016/j.nedt.2011.11.006

Lash, D. B., Barnett, M. J., Parekh, N., Shieh, A., Louie, M. G., \& Tang Terrill, T. L. (2014). Perceived benefits and challenges of IPE-based on a multidisciplinary faculty member survey. American Journal of Pharmacy Education, 78(10), 180. Retrieved from http://www.ncbi.nlm.nih.gov/pmc/articles/PMC4315202/

Lawlis, T. R., Anson, J., \& Greenfield, D. (2014). Barriers and enablers that influence sustainable IPE: A literature review. Journal of Interprofessional Care, 28(4), 305-310. http://dx.doi.org/10.3109/13561820.2014.895977

Lewy, L. (2010). The complexities of interprofessional learning/working: Has the agenda lost its way? Health Education Journal, 69(1), 4-12. http://dx.doi.org/10.1177/0017896910363299

McFadyen, A. K., Maclaren, W. M., \& Webster, V. S. (2007). The interdisciplinary education perception scale (IEPS): An alternative remodeled sub-scale structure and its reliability. Journal of Interprofessional Care, 21(4), 433-443. http://dx.doi.org/10.1080/13561820701352531

Meffe, F., Moravac, C. C., \& Espin, S. (2012). An interprofessional education pilot program in maternity care: Findings from an exploratory case study of undergraduate students. Journal of Interprofessional Care, 26(3), 183-188. http://dx.doi.org/10.3109/13561820.2011.645089 
Mellor, R., Cottrell, N., \& Moran, M. (2013). "Just working in a team was a great experience..." Student perspectives on the learning experiences of an IPE program. Journal of Interprofessional Care, 27(4), 292-297. http://dx.doi.org/10.3109/13561820.2013.769093

Paul, P., Olson, J. K., Sadowski, C., Parker, B., \& Alook, A. (2014). Interprofessional simulation learning with nursing and pharmacy students: A qualitative study. Qualitative Advancement in Nursing Education, 1(1), 1-6. http://dx.doi.org/10.17483/23686669.1011

Pett, M. A. (1997). Nonparametric statistics for health care research. Statistics for small samples and unusual distributions. Thousand Oaks, CA: Sage.

Pfaff, K., Baxter, P., Jack, S., \& Ploeg, J. (2013). An integrative review of the factors influencing new graduate nurse engagement in interprofessional collaboration. Journal of Advanced Nursing, 70(1), 4-20. http://dx.doi.org/10.1111/jan.12195

Polit, D.F., \& Beck, C. (2008). Nursing research. Generating and assessing evidence for nursing practice (8th ed.). Philadelphia, PA: Wolter Kluwer, Lippincott Williams \& Wilkins.

Proctor, P., Lake, D., Jewell, L., Racine, L., D’Eon, M., \& Reeder, B. (2010). Influencing student beliefs about poverty and health through interprofessional community-based educational experiences. Journal of Research in Interprofessional Practice and Education, 1(2), 145158.

Racine, L., Proctor, P., \& Jewell, L. M. (2012). Putting the world as classroom: An application of the inequalities imagination model in nursing and health education. Journal of Transcultural Nursing, 23(1), 90-99. http://dx.doi.org/10.1177/1043659611423832

Ravet, J. (2012). From interprofessional education to interprofessional practice: Exploring the implementation gap. Professional Development in Education, 38(1), 49-64. http://dx.doi.org/10.1080/19415257.2011.576263

Reeves, S., Goldman, J., Gilbert, J., Tepper, J., Silver, I., Suter, E., \& Zwarenstein, M. (2011). A scoping review to improve conceptual clarity of interprofessional interventions. Journal of Interprofessional Care, 25(3), 167-174. http://dx.doi.org/10.3109/13561820.2010.529960

Reeves, S., Perrier, L., Goldman, J., Freeth, D., \& Zwarenstein, M. (2013). IPE: Effects on professional practice and healthcare outcomes (update). Cochrane Database of Systematic Reviews, 3. Retrieved from http://www.thecochranelibrary.com/view/0/index.html

Robben, S., Perry, M., van Nieuwenhuijzen, L., van Achterberg, T., Rikkert, M. O., Schers, H., ... Melis, R. (2012). Impact of IPE on collaboration attitudes, skills, and behavior among primary care professionals. Journal of Continuing Education in the Health Professions, 32(3), 196-204. http://dx.doi.org/10.1002/chp.21145

Salfi, J., Solomon, P., Allen, D., Mohaupt, J., \& Patterson, C. (2012). Overcoming all obstacles: A framework for embedding interprofessional education into a large, multisite Bachelor of Science nursing program. Journal of Nursing Education, 51(2), 106-110. http://dx.doi.org/10.3928/01484834-20111230-05 
Salvatori, P. S., Berry, S. C., \& Eva, K. W. (2007). Implementation and evaluation of an IPE initiative for students in the health professions. Learning in Health and Social Care, 6(2), 72-82. http://dx.doi.org/10.1111/j.1473-6861.2007.00152.x

Saxell, L., Harris, S., \& Elarar, L. (2009). The collaboration for maternal and newborn health: Interprofessional maternity care education for medical, midwifery, and nursing students. Journal of Midwifery \& Women's Health, 54(4), 314-320. http://dx.doi.org/10.1016/j.jmwh.2009.03.017

Shafran, D. M., Richardson, L., \& Bonta, M. (2015). A novel interprofessional shadowing initiative for senior medical students. Medical Teacher, 37(1), 86-89. http://dx.doi.org/10.3109/0142159x.2014.929099

Shiyanbola, O. O., \& Lammers, C. (2012). Evaluation of a student-led interprofessional innovative health promotion model for an underserved population with diabetes: A pilot project. Journal of Interprofessional Care, 26(5), 376-382. http://dx.doi.org/10.3109/13561820.2012.685117

Shiyanbola, O. O., Randall, B., Lammers, C., Hegge, K. A., \& Anderson, M. (2014). Impact of an interprofessional diabetes education model on patient health outcomes: A longitudinal study. Journal of Research in Interprofessional Practice and Education, 4(2), 1-21.

Simmons, B., Oandasan, I., Soklaradis, S., Esdaile, M., Barker, K., Kwan, D., ... Wagner, S. (2011). Evaluating the effectiveness of an IPE faculty development course: The transfer of interprofessional learning to the academic and clinical practice setting. Journal of Interprofessional Care, 25(2), 156-157. http://dx.doi.org/10.3109/13561820.2010.515044

Sinfield, P., Donoghue, K., Horobin, A., \& Anderson, E. S. (2012). Placing interprofessional learning at the heart of improving practice: The activities and achievements of CLAHRC in Leicestershire, Northamptonshire, and Rutland. Quality in Primary Care, 20(3), 191198.

Solomon, P., \& Salfi, J. (2011). Evaluation of an IPE communication skills initiative. Education for Health, 24(2), 1-10.

Solomon, P., Baptiste, S., Hall, P., Luke, R., Orchard, C., Rukholm, E., ... Damiani-Taraba, G. (2010). Students' perceptions of interprofessional learning through facilitated online learning modules. Medical Teacher, 32(9), e391-e398.

http://dx.doi.org/10.3109/0142159x.2010.495760

Steinert, Y. (2005). Learning together to teach together: Interprofessional education and faculty development. Journal of Interprofessional Care, 19(Suppl. 1), 60-75. http://dx.doi.org/10.1080/13561820500081778

Suchman, A. L. (2006). Control and relation: Two foundational values and their consequences. Journal of Interprofessional Care, 20(1), 3-11. http://dx.doi.org/10.1080/13561820500497941

Tashiro, J., Byrne, C., Kitchen, L., Vogel, E., \& Bianco, C. (2011). The development of competencies in interprofessional health care for use in health science educational programs. Journal of Research in Interprofessional Practice and Education, 2(1), 63-82.

Thorne, S. (2008). Interpretive description. Walnut Creek, CA: Left Coast Press. 
Wilcock, P. M., Janes, G., \& Chambers, A. (2009). Health care improvement and continuing IPE: Continuing interprofessional development to improve patient outcomes. Journal of Continuing Education in the Health Professions, 29(2), 84-90. http://dx.doi.org/10.1002/chp.20016

Yarborough, M., Jones, T., Cyr, T. A., Phillips, S., \& Stelzner, D. (2000). IPE in ethics at an academic health sciences center. Academic Medicine, 75(8), 793-800. http://dx.doi.org/10.1097/00001888-200008000-00009 